\title{
CONTROL TESTS FOR GROWING UP BASKETBALL PLAYERS
}

\section{Mariana Borukova}

National Sports Academy "Vassil Levski", Sofia, Bulgaria

\begin{abstract}
The introduction of an updated test battery, covering tests accessible for all age groups and with duration of one training session is needed for the execution of effective control on the growing up basketball players. The purpose of the

OPEN ACCESS

Submitted: 10 October 2021 Accepted: 25 November 2021

ORCID (D)

Mariana Borukova https://orcid.org/0000-0003-4403-9065

Cite this article as:

Borukova, M. (2021).

Control tests for growing up

basketball players Journal of Applied Sports Sciences, Vol.2, pp. 51-65. DOI: $10.37393 / J A S S .2021 .02 .5$

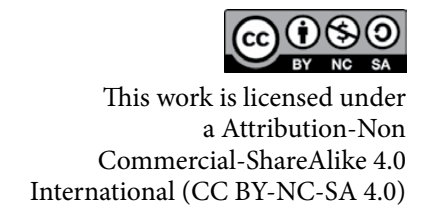
study was to create an updated test battery for basketball players (boys and girls) of U12, U14, and U16, including three groups of indicators: for physical development, physical preparedness, and technical skills. Three hundred and ten children from the clubs in the country (137 boys and 173 girls) participated in the sport-pedagogical tests. We applied a new test battery, covering 21 indicators, divided into three groups: for physical development, physical preparedness, and technical skills. The results were processed with a variation analysis and comparative analysis by the t-criterion of Student. The results showed statistically important differences for both sexes between U12 and U14 for the physical development and physical preparedness signs and for some tests in relation to the technical preparedness. An important difference was observed between U14 and U16 from both sexes for some of the sings only; as far as the technical skills were concerned, the differences for the boys were due to occasional reasons; for the U16 girls, they were considerably better than the U14 girls. The new test battery objectively reflects the real status of the level of all U12, U14, and U16 competitors. Normative tables will be developed to help the work of the coaches in relation to the optimization of the school-training process.
\end{abstract}

Keywords: Test battery, Basketball players U12, U14 and U16, Control

\section{INTRODUCTION}

The complex development of the motive qualities sets up the issue related to the evaluation and control of the specific functional preparation of the growing up competitors. Many researchers developed specific basketball tests and indicators for the purpose (Dasheva, 1991, Zheliazkov and Kelle, 1993). The introduction of puslemetry, the control on $\mathrm{La}, \mathrm{BE}, \mathrm{VO}_{2} \max$ and other bio-chemical and physiological indicators contributed considerably, in that respect. The evaluation of the young competitors' preparedness degree is often necessary in basketball practice. Thus, the necessary information is received serving as a landmark for their development level - whether they possess the needed physical qualities and basketball skills, whether they are progressing in the school-training process and whether there is a prospect for them to develop as highly-qualified competitors in future (Karalejič and Jakovljevič, 2001).

The first basketball test batteries were related to the specific motive skills. They appeared in the early 1930s and were developed in various periods by D. Brace (1924) and J. Young, K. Moser (1934). During the second half of the century, there were already tests related to the basketball technical skills. A great variety of test batteries, including combinations of various tests are found in the specific basketball literature sources (Temkov, 1956, Semov, 1973, Petrov, 1998, Tzarova, 1981, Zheliazkov et al., 1984, Gyosheva et al., 1990, Pattison, 1990, Karalejič and Jakovljevič, 2001, Tsarova and Tsarov, 2007). Also, three systems for control, evaluation, and optimization of the sports preparation were developed and implement- 
ed in practice (Gyosheva et al., 1990). Today many basketball experts use the test battery developed by AAHPERD (American Alliance for Health, Physical Education, Recreation and Dance), covering 4 tests for specific basketball skills: quick shooting for $60 \mathrm{sec}$; test for passing on and moving; test for dribble control and test for moving in defense.

The processing of the quantitative information with the help of adequate mathematic-statistic methods and the deep analysis of the data allow for the developing of normative base for control and optimization of the competitive effectiveness of the respective totality. The establishment of such a base is one of the most important conditions for the optimization of sports preparation (Tsarov, 2012).

The scientific and practical experience of basketball experts is exceptionally important for achieving high-effective control. Over our rich experience for setting up sport-pedagogical tests in basketball for coming generations, we have established that the existing test batteries are difficult to apply by coaches as the tests are numerous and require more than one training session. Based on coaches' enquiry information, we have established that the creation of a modern test battery applied within the frames of one training session of $120 \mathrm{~min}$, including tests which are similar for all age groups but differ in relation to the loading and duration, shall optimize the work. Analyzing various test batteries from leading basketball schools such as the Spanish, Russian, American, Serbian, and Australian ones, we have established that additionally to the tests for the physical development and physical preparedness, there should be others similar to the 4 tests presented by AAHPERD. That is why we combined tests from the schools mentioned herein above with total duration time of 120 $\min$. To achieve more effective control, 50 rate normative system will be developed to the test battery while the normative tables shall be presented respectively by sex and age; for girls up to U12, U14 and up to U16 and for boys up to U12, U14, and U16.

The analysis of the facts mentioned above, our personal experience and observations provide us with the reason to admit that for both sexes aged up to 12 , up to 14 , and up to 16 years there are statistically important differences in relation to some anthropometric characteristics, physical preparedness, and basketball skills. The introduction of a test battery and an actual normative system could facilitate the work of coaches in relation to the optimization of the school-training process.

The purpose of this study was to create an updated test battery for U12, U14, and U16 male and female basketball players covering three groups of indicators: physical development, physical preparedness, and technical skills.

\section{METHODOLOGY}

The study was carried out from March 2021 to September 2021.

\section{Participants}

The research was done among 310 children -137 boys and 173 girls, divided into three age groups as follows: U12 - total 117 (45 boys and 71 girls); U14 - total 104 (45 boys and 49 girls) and U16 - total 99 (47 boys and 53 girls).

All participants were male and female basketball competitors - members of various clubs in Bulgaria for the respective age group and taking part in the State Basketball Championship, while some of them were members of the national teams for the respective age. Everybody practices basketball in organized forms and their sports experience depends on their age. The clubs in the country work according to the Unified Teaching Methodology, introduced by the Bulgarian Basketball Federation in 2018. 


\section{RESEARCH METHODS AND INDEXES}

\section{Procedure}

The participants underwent sport-pedagogical testing for the needs of the study and for probating and standardizing the specific test battery. Informed consent and parental permission for all tested participants were obtained for the testing procedure. The study was conducted under the principles stated in the Declaration of Helsinki for human studies and in compliance with the ethical code of the National Sports Academy. Each test was performed twice by the participants and a correlation analysis of both results was made for the needs of the study; the better achievements were processed, and the data were included in the Normative system. Table 1 presents Boru- kova's test battery (2021). The test battery covers 21 indicators bearing information about the physical development basic signs, the physical preparedness, and the basketball technical skills. The indicators are divided into three groups: for physical development from $1^{\text {st }}$ to $7^{\text {th }}$ indicator; for physical preparedness from $8^{\text {th }}$ to $14^{\text {th }}$ indicator and for technical skills from $15^{\text {th }}$ to $21^{\text {st }}$ indicator. The tests for physical development and physical preparedness are standard ones used in sports practice for many years already; indicator 13 "Shuttle run" will be described only as it is somewhat different from the one used till now. The technical skills tests are new for the Bulgarian coaches and competitors and for better clearness and perception of the information, they should be described.

Table 1. Description of Borukova's test battery (2021)

\begin{tabular}{|c|c|c|c|c|}
\hline № & Indexes & 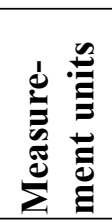 & 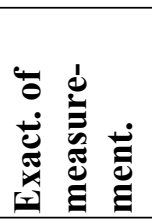 & 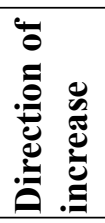 \\
\hline 1. & Height & $\mathrm{cm}$ & 1,0 & + \\
\hline 2. & Weight & $\mathrm{kg}$ & 0,5 & \\
\hline 3. & Body Mass Index & $\mathrm{kg} / \mathrm{m}^{2}$ & 0,01 & \\
\hline 4. & Horizontal extension & $\mathrm{cm}$ & 1,0 & + \\
\hline 5. & Vertical extension & $\mathrm{cm}$ & 1,0 & + \\
\hline 6. & Chest measurement - Pause & $\mathrm{cm}$ & 1,0 & + \\
\hline 7. & Chest measurement - respiratory difference & $\mathrm{cm}$ & 1,0 & + \\
\hline 8. & Sprint $20 \mathrm{~m}$ & $\mathrm{~s}$ & 0,01 & - \\
\hline 9. & Long jump & $\mathrm{m}$ & 0,01 & + \\
\hline 10. & Vertical jump & $\mathrm{cm}$ & 1,0 & + \\
\hline 11. & Maximum Vertical jump & $\mathrm{cm}$ & 1,0 & + \\
\hline 12. & Flexibility & $\mathrm{cm}$ & 1,0 & + \\
\hline 13. & "Shuttle" run (Figure 1) & $\mathrm{s}$ & 0,01 & - \\
\hline 14. & Test for swift-moving along the ground (Figure 2) & s & 0,01 & - \\
\hline 15. & Dribble and shooting at high speed (Figure 3) & s & 0,01 & - \\
\hline 16. & Ball keeping index & s & 0,01 & - \\
\hline 17. & Catching and passing, shooting the basket (Figure 4) & $\mathrm{s}$ & 0,01 & - \\
\hline 18. & Catching, passing, shooting the basket index & $\mathrm{s}$ & 0,01 & - \\
\hline 19. & Shooting - time (Figure 5) & $\mathrm{s}$ & 0,01 & - \\
\hline 20. & Shooting - score & $\%$ & 0,01 & + \\
\hline 21. & Free throw & $\%$ & 0,01 & + \\
\hline
\end{tabular}


13. 'Shuttle" run - always from baseline to baseline and then to each closer line on the court. Short sprints are made by changing the direction along the route, as shown in Figure 1. The participant should step with one foot on the respective line at each change of the direction. Performance time is recorded with exactness of $0.01 \mathrm{~s}$. All age groups perform the test the way described in Figure 1.

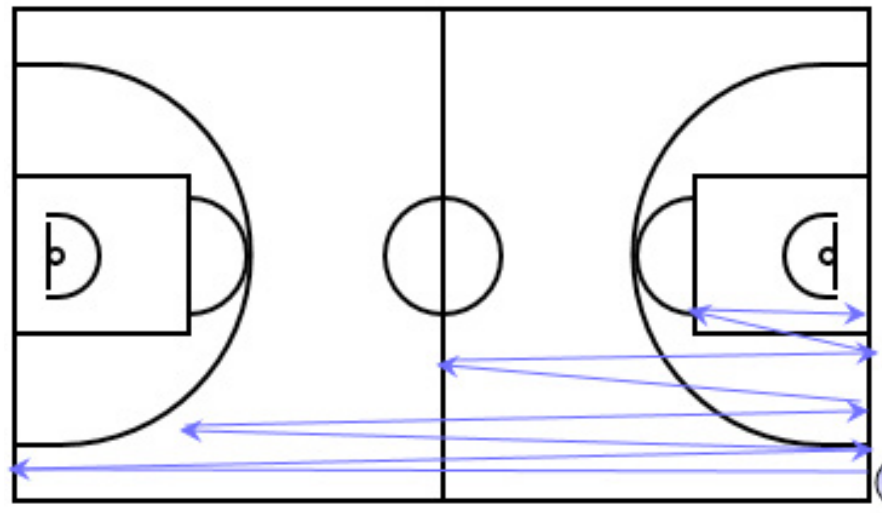

Legend:

Player movement

without a ball

Start/Final

Figure 1. Shuttle run

Description of the technical skills tests: of the paint, defense moving is again fulfilled

14. Test for swtift-moving along the court along the paint, running backwards along the without a ball (for agility). From high starting position, with face turned to the center of the court, the competitor moves along the route shown in Figure 2 along the lines of the basketball court: defense moving is fulfilled along the baseline to the paint, sprint - facing the line boundaries of the paint, defense movement is again fulfilled along the baseline. It is performed in both directions - going on and turning back. The direction of moving is by choice - right or left. The result is recorded with exactness of $0.01 \mathrm{~s}$.

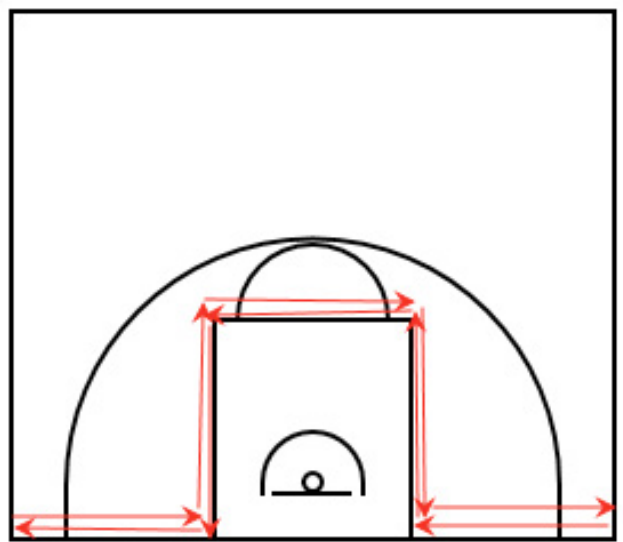

Legend:

Player movement

without a ball

Start/Final

Figure 2. Test for swift-moving along the court without a ball (for agility)

15. Dribble, change of direction at high speed, and shooting while moving. The competitor goes along the route shown in Figure
3. He/she performing the exercise stands still at the baseline, next to the cone, at a signal, he/she dribbles with the left hand in the di- 
rection of the paint line, passes in front of the cone changing the dribbling hand. Upon each pass in front of the cone, the leading hand is changed. After the last cone, shooting while moving is performed from two-step rhythm finishing with the right hand. Following the shooting, the ball is taken, and the person starts his/her way back in the same way while dribbling with the right hand, upon passing in front of the cones, changes the leading hand, and after the last cone shoots while moving from two-step rhythm, finishing with the left hand. The result is recorded with exactness of up to $0.01 \mathrm{~s}$ and the number of the baskets scored is counted. For each basket, $1 \mathrm{~s}$ is taken off, for each ball dropped down or technical mistake, $1 \mathrm{~s}$ is added.

\section{Start/Final}

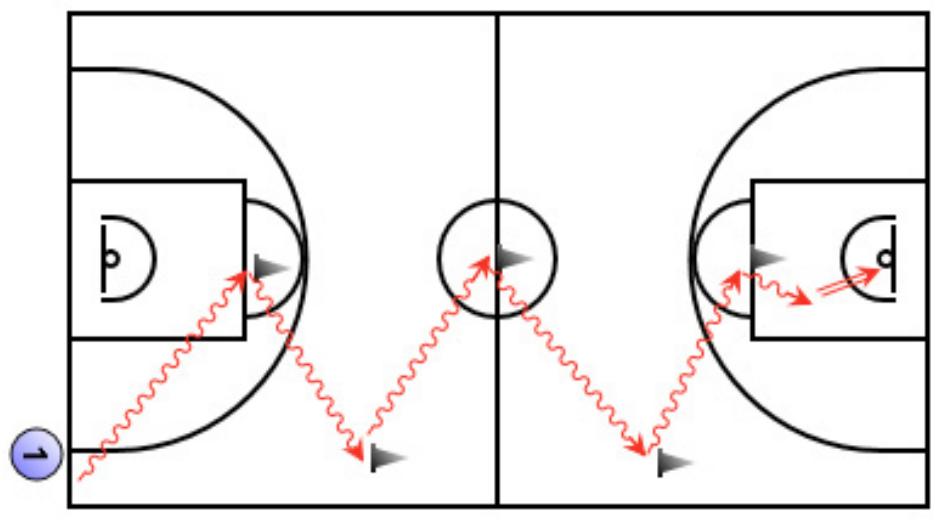

\section{Legend:}

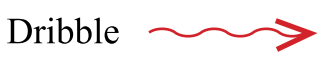

Shot

Figure 3. Dribble, change of direction at high speed, and shooting while moving.

Equipment: 5 cones, 1 basketball, and a chronometer.

Instructions:

\section{For U12}

- crossed change of direction is performed;

- 1 tour is passed-going on and coming back ( 2 shootings -1 with the right hand and 1 with the left hand).

\section{For U14}

16. Catching, passing on while moving, and shooting while moving. The competitor executing the test passes along the route shown in Figure 4. The person under study stays in front of the board, next to the cone, shoots at the board, jumps up and catches the ball, passes on to $\mathrm{X} 1$, runs towards the opposite basket, gets a pass from X1 and passes to $\mathrm{X} 2$, runs towards the basket, again receives the ball from $\mathrm{X} 2$, passes to $\mathrm{X} 3$ and after the free-throw line receives the ball and shoots
- change of direction with the leading foot;

- 2 tours are passed (4 shootings -2 with the right and 2 with the left hand).

\section{For U16}

- change direction with a spin move Rowling;

- 3 tours are passed (6 shootings -3 with the right and 3 with the left hand).

while moving from two-step rhythm, finishing with the right hand. Following the shooting, the player gets the ball and goes back in the same way, passing on again consecutively to $\mathrm{X} 1, \mathrm{X} 2$, and $\mathrm{X} 3$, shooting under the basket with the left hand. The result is recorded with exactness to $0.01 \mathrm{~s}$ and the baskets made are counted. For each basket scored, 1s is deleted and for each dropped ball or technical mistake, $1 \mathrm{~s}$ is added. 


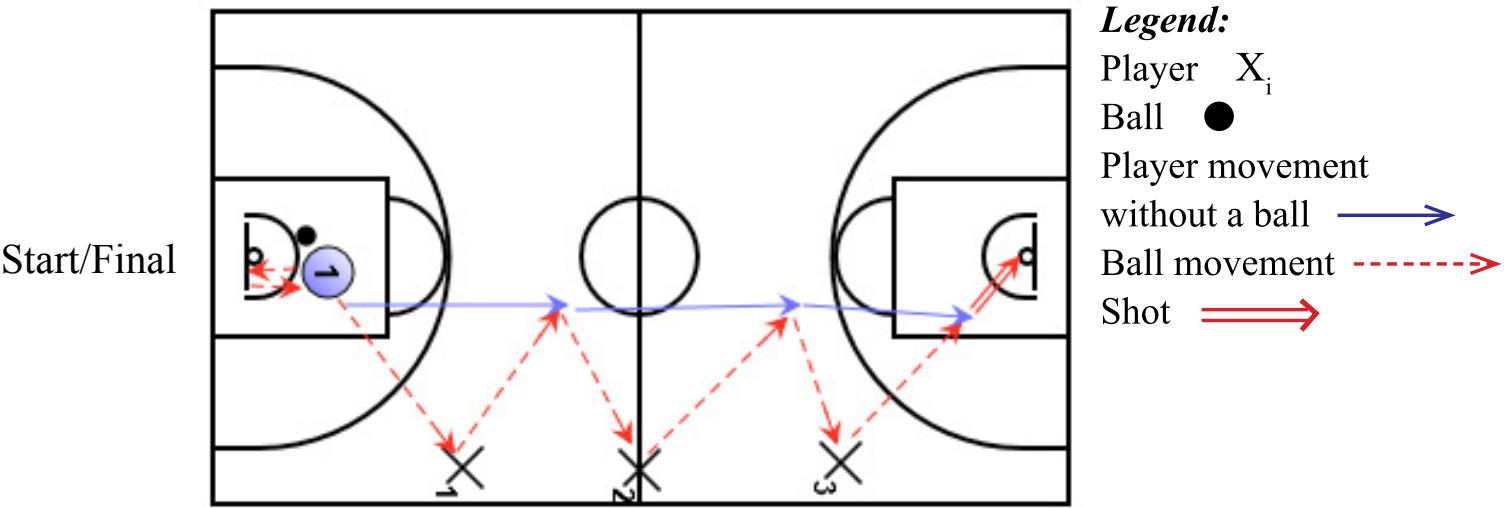

Figure 4. Catching, passing on while moving, and shooting while moving.

Equipment: 1 cone, 1 basketball, a chronometer, and 3 feeders.

Instructions:

1. For U12

- passing on with two hands;

- 1 tour is passed - going on and coming back ( 2 shootings -1 with the right hand and 1 with the left hand).

2. For U14

17. Shooting into the basket for $1 \mathrm{~min}$ ly from the positions, shown in Figure 5 within from 5 positions for 3 points and 5 positions 1 minute. for 2 points - each player shoots independent-
- passing on with one hand;

- 2 tours are passed (4 shootings -2 with the right and 2 with the left hand).

3. For U16

- passing on according to the wish of the player;

- 3 tours are passed (6 shootings -3 with the right and 3 with the left hand).

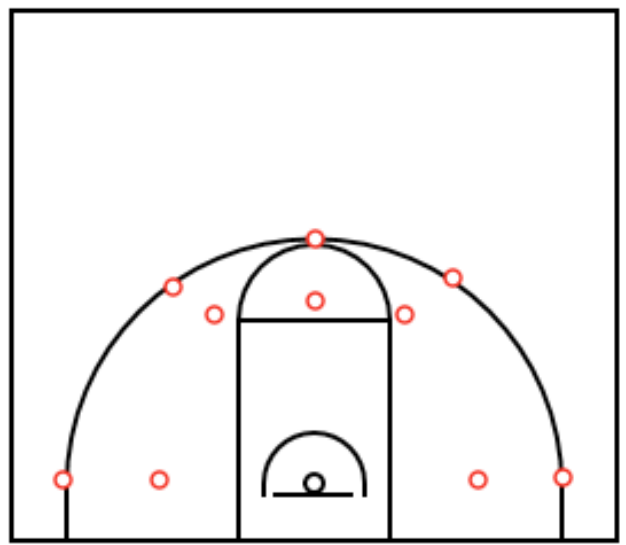

Legend:

Shoting position

Figure 5. Shooting into the basket for 1 min from 5 positions for 3 points and 5 positions for 2 points

Instructions:

1. For U12. The player performs 10 shootings from 5 points shown in Figure 5 (at 3.5 $\mathrm{m}$ from the projected center of the ring to the floor) twice from each position. Two series are performed with 1 min rest in between them. The number of the baskets made is recorded.

2. For U14 and U16. The player shoots from each position marked while the first shooting is for 3 points, the second one - inside the three- 
point line - for 2 points. The player should go through all positions marked for 1 minute. Performed are $2 \times 10$ shootings with 1-minute rest in between both series. The number of the shootings and successful points is recorded.

18. Free throws. Performed in pairs while each one should shoot 5 series of 2 free throws (total 10) with a feeder. The number of the successful free throws is recorded. The relative share (in \%) of the successful shots into the basket from the total number of free throws made is recorded as the result from the test.

The sport-pedagogical tests are applied by one and the same researcher or coach of the respective team at terrain conditions within one training session (120 min); second-year students with a major "Basketball coach" at NSA took part in the education process. The anonymity of the children was guaranteed; each one was listed under different number, known to the team coach only. Everybody participated voluntarily in the research and did not receive money or financial compensation for their contribution. None of the participants refused to take part in the study except those who were injured or were not feeling well. Short instructions, video, and demonstration of the test battery were provided prior the tests. The research was carried out in standard conditions - a basketball hall with the necessary equipment: a chronometer, measuring apparatuses, cones, and basketballs. The participants performed the tests twice. The better achievements were recorded for the analysis of the results.

The following research methods were applied for the realization of the purpose and tasks of the study: review study of specific literature and sport-pedagogical testing.

\section{Data analysis}

The results of the study were subjected to mathematic-statistical processing with SPSS 23; depending on the tasks of the study, the following statistical methods were applied: variation analysis, correlation analysis, and comparative analysis by t-criterion of Student at reliability level of $P t \geq 95 \%$.

\section{RESULTS}

The results from the variation analysis of the physical development indicators under study for the girls and boys showed that the values were normally distributed and the totalities under study were homogeneous and relatively homogeneous in relation to the signs about which these indicators bear information. All three age groups were homogeneous along four signs: height, horizontal and vertical extension, and chest measurement - pause. The latest studies conducted by a scientific team R. Tsarova and M. Borukova during the period 2012/2015 of male and female basketball players from 12 to 16 years of age established that the current competitors from all age groups have much lower results in comparison with the previous generations. The tendency is reduction of the results by each year (Borukova, 2018). Due to the large volume of data, we present only the data of indicators related to physical preparedness of boys and girls (Table 2). The results from the variation analysis for the physical preparedness indicators of the boys and the girls showed that the values had normal distribution too; the totalities under study were homogeneous and relatively homogeneous in relation to the signs under study. The groups of the girls were homogeneous along three signs related to the explosive strength of the lower limbs as regards moving, suppleness, and agility of moving down the court without a ball. Homogeneity and relative homogeneity for various indicators were observed for the separate age groups. Non-homogeneity was observed for "Shuttle run" indicator related to U16 age group (Table 2). 
Table 2. Mean values and dissipation of indicators of physical preparedness

\begin{tabular}{lcccccccc}
\hline \multirow{2}{*}{ Age Indicators } & \multicolumn{4}{c}{ Boys } & \multicolumn{4}{c}{ Girls } \\
\cline { 2 - 9 } & $\mathbf{N}$ & $\mathbf{X}$ & $\mathbf{S}$ & $\mathbf{V}$ & $\mathbf{N}$ & $\mathbf{X}$ & $\mathbf{S}$ & $\mathbf{V}$ \\
\hline Sprint $20 \mathrm{~m}$ & 45 & 3.87 & .273 & 7.05 & 71 & 4 & .332 & 8.3 \\
Long jump & 45 & 1.76 & .188 & 10.66 & 71 & 1.65 & .202 & 12.27 \\
Vertical jump & 45 & 35.36 & 7.388 & 20.9 & 71 & 29.41 & 6.303 & 21.43 \\
12 Maximum vertical jump & 45 & 40.00 & 9.700 & 24.38 & 71 & 33.00 & 10.000 & 29.31 \\
Flexibility & 45 & 96.82 & 9.074 & 9.37 & 71 & 100.64 & 6.703 & 6.66 \\
"Shuttle" run & 45 & 34.75 & 3.38 & 9.73 & 71 & 34.43 & 3.113 & 9.04 \\
Test for swift-moving along the ground & 45 & 19 & 2.099 & 11.05 & 71 & 19.65 & 1.865 & 9.49 \\
\hline Sprint 20 m & 45 & 3.53 & .254 & 7.19 & 49 & 3.82 & .633 & 16.57 \\
Long jump & 45 & 2.03 & .238 & 11.73 & 49 & 1.76 & .164 & 9.35 \\
Vertical jump & 45 & 45.19 & 9.049 & 20.02 & 49 & 32.41 & 5.377 & 16.59 \\
Maximum vertical jump & 45 & 59.00 & 10.900 & 18.34 & 49 & 38.00 & 6.600 & 17.10 \\
Flexibility & 45 & 101.38 & 6.29 & 6.2 & 49 & 105.89 & 7.128 & 6.73 \\
"Shuttle" run & 45 & 30.79 & 2.997 & 9.74 & 49 & 33.76 & 1.231 & 3.65 \\
Test for swift-moving along the ground & 45 & 16.43 & 1.024 & 6.23 & 49 & 18.06 & 1.154 & 6.39 \\
\hline Sprint 20 $\mathrm{m}$ & 47 & 3.4 & .25 & 7.37 & 53 & 3.78 & .189 & 5.01 \\
Long jump & 47 & 2.28 & .243 & 10.65 & 53 & 1.8 & .221 & 12.27 \\
Vertical jump & 47 & 55.36 & 8.45 & 15.26 & 53 & 36.78 & 6.034 & 16.4 \\
Maximum vertical jump & 47 & 70.00 & 9.900 & 15.50 & 53 & 45.00 & 7.100 & 15.81 \\
Flexibility & 47 & 103.36 & 7.702 & 7.45 & 53 & 109.23 & 5.714 & 5.23 \\
"Shuttle" run & 47 & 30.45 & 2.486 & 8.17 & 53 & 32.68 & 1.938 & 5.93 \\
Test for swift-moving along the ground & 47 & 15.88 & 1.278 & 8.05 & 53 & 17.06 & .96 & 5.63 \\
\hline
\end{tabular}

The groups of the boys of all ages were homogeneous along six signs related to the speed abilities, explosive strength of the lower limbs as regards standing and moving, suppleness, speed endurance, and agility while moving down the court without a ball. Relative homogeneity was observed only in relation to the explosive strength of the lower limbs while standing for all three age groups. Boys' strength develops actively after the puberty while the age groups studied by us are still in the phase of puberty development.

The U12 and U16 girls' groups were homogeneous along two signs related to the time for the execution of 10 shootings towards the basket as far as the technical preparedness is concerned. Relative homogeneity and non-homogeneity were observed in relation to all the rest of the signs under study for the separate age groups. Unfortunately, that is a bad sign showing that the competitors from the various age groups have difficulties with executing the technique at high speed which is very important for the game.

Strong homogeneity in relation to dribbling the ball and passing on at high speed, as well as the difference "dribble-scored" and the difference "passing on-scored" was observed for the same group of indicators among the U14 boys. The U16 group was homogeneous along one sign only related to the time of executing 10 shootings towards the basket. Relative homogeneity and non-homogeneity were observed in relation to all the other signs for the separate age groups. It can be generalized for the boys as well that it is a bad sign showing that the young U12 male basketball players have difficulties performing the technique at high speed while it is the ability to score baskets for the older groups.

The analysis made so far does not allow for making generalized conclusions. The compar- 
ative analysis by $t$-criterion of Student for independent samples at statistical reliability of $\mathrm{Pt} \geq$ 95\% was applied for checking up the zero-hypothesis related to the importance of the differences observed between the average levels of the signs under study for the different totalities (U12, U14, and U16 male basketball players as well as U12, U14 and U16 female basketball players). Having in mind the great differences due to the biological development of both sexes, a comparison between U12 and U16 was not applied. A comparison was not made in relation to the "Dribble and shooting at high speed" and "Catching and passing on, shooting towards the basket" indicators; these tests have different requirements for execution and time duration for each age group. Table 3 and Table 4 present the comparative analysis between the average for the U12 and U14 boys $\left(t_{\text {critical }}=1,98\right)$ and $\mathrm{U} 14$ and $\mathrm{U} 16$ boys $\left(t_{\text {critical }}=1,98\right)$.

Table 3. Importance of the differences for U12 and U14 boys

\begin{tabular}{|c|c|c|c|c|c|c|c|}
\hline Indicators & Age & $\mathbf{N}$ & Mean & $\mathbf{S t}$ & $\mathbf{F}$ & $\mathbf{t}$ & Sig. \\
\hline \multirow{2}{*}{ Height } & 12 & 45 & 1.53 & .089 & 1.998 & 9.514 & 0 \\
\hline & 14 & 45 & 1.71 & .098 & & & \\
\hline \multirow{2}{*}{ Weight } & 12 & 45 & 43.24 & 10.014 & 5.036 & 6.584 & 0 \\
\hline & 14 & 45 & 59.32 & 12.971 & & & \\
\hline \multirow{2}{*}{ BMI } & 12 & 45 & 18.37 & 2.987 & .150 & 2.553 & .012 \\
\hline & 14 & 45 & 20.02 & 3.158 & & & \\
\hline \multirow{2}{*}{ Horizontal extension } & 12 & 45 & 1.52 & .100 & 2.004 & 9.640 & 0 \\
\hline & 14 & 45 & 1.73 & .109 & & & \\
\hline \multirow{2}{*}{ Vertical extension } & 12 & 45 & 1.98 & .123 & 4.408 & 9.666 & 0 \\
\hline & 14 & 45 & 2.27 & .154 & & & \\
\hline \multirow{2}{*}{ Chest measurement - Pause } & 12 & 45 & 73.64 & 6.898 & .140 & 6.219 & 0 \\
\hline & 14 & 45 & 83.13 & 7.561 & & & \\
\hline \multirow{2}{*}{$\begin{array}{l}\text { Chest measurement - respiratory } \\
\text { difference }\end{array}$} & 12 & 45 & 6.94 & 1.362 & 4.280 & 3.702 & 0 \\
\hline & 14 & 45 & 8.10 & 1.590 & & & \\
\hline \multirow{2}{*}{ Sprint $20 \mathrm{~m}$} & 12 & 45 & 3.87 & .273 & .099 & 6.139 & 0 \\
\hline & 14 & 45 & 3.53 & .254 & & & \\
\hline \multirow{2}{*}{ Long jump } & 12 & 45 & 1.76 & .188 & 4.878 & 6.002 & 0 \\
\hline & 14 & 45 & 2.03 & .238 & & & \\
\hline \multirow{2}{*}{ Vertical jump } & 12 & 45 & 35.36 & 7.388 & 5.467 & 5.647 & 0 \\
\hline & 14 & 45 & 45.19 & 9.049 & & & \\
\hline \multirow{2}{*}{ Maximum Vertical jump } & 12 & 45 & 39.63 & 9.660 & 7.428 & 8.790 & 0 \\
\hline & 14 & 45 & 58.77 & 10.550 & & & \\
\hline \multirow{2}{*}{ Flexibility } & 12 & 45 & 96.82 & 9.074 & 2.990 & 2.768 & .007 \\
\hline & 14 & 45 & 101.38 & 6.290 & & & \\
\hline \multirow{2}{*}{ "Shuttle" run } & 12 & 45 & 34.75 & 3.380 & .034 & 5.892 & 0 \\
\hline & 14 & 45 & 30.79 & 2.997 & & & \\
\hline \multirow{2}{*}{ Swift moving along the ground } & 12 & 45 & 19.00 & 2.099 & 16.247 & 7.387 & 0 \\
\hline & 14 & 45 & 16.43 & 1.024 & & & \\
\hline \multirow{2}{*}{ Shooting from position - time } & 12 & 45 & 52.26 & 9.474 & .001 & 5.249 & 0 \\
\hline & 14 & 45 & 61.97 & 8.010 & & & \\
\hline \multirow{2}{*}{ Shooting for 2 points } & 12 & 45 & 3.36 & 1.824 & 3.783 & 3.542 & .001 \\
\hline & 14 & 45 & 2.18 & 1.284 & & & \\
\hline \multirow{2}{*}{ Free throws } & 12 & 45 & 51.78 & 21.029 & .616 & 3.190 & .002 \\
\hline & 14 & 45 & 65.11 & 18.540 & & & \\
\hline
\end{tabular}


Table 3 analysis shows that the calculated the differences observed between the average values of $t$-criterion were higher than the crit- levels of the signs under study for U12 and ical $\left(t_{\text {critical }}=1.98\right)$ one for all indicators. That U14 were statistically significant. That fact allows us, with high guaranteed probability, to was also confirmed by the level of importance reject the zero hypothesis and accept as true $\alpha$, taking values under 05 .

the alternative hypothesis according to which

Table 4. Importance of the differences for U14 and U16 boys

\begin{tabular}{|c|c|c|c|c|c|c|c|}
\hline Indicators & Age & $\mathbf{N}$ & Mean & $\mathbf{S}$ & $\mathbf{F}$ & $\mathbf{t}$ & Sig. \\
\hline \multirow{2}{*}{ Height } & 14 & 45 & 1.71 & .098 & 1.397 & 4.493 & 0 \\
\hline & 16 & 47 & 1.80 & .089 & & & \\
\hline \multirow{2}{*}{ Weight } & 14 & 45 & 59.32 & 12.971 & 4.852 & 3.948 & 0 \\
\hline & 16 & 47 & 68.82 & 9.983 & & & \\
\hline \multirow{2}{*}{ BMI } & 14 & 45 & 20.02 & 3.158 & 1.620 & 1.904 & .06 \\
\hline & 16 & 47 & 21.19 & 2.733 & & & \\
\hline \multirow{2}{*}{ Horizontal extension } & 14 & 45 & 1.73 & .109 & 7.085 & 4.233 & 0 \\
\hline & 16 & 47 & 1.82 & .090 & & & \\
\hline \multirow{2}{*}{ Vertical extension } & 14 & 45 & 2.27 & .154 & 7.895 & 3.034 & .003 \\
\hline & 16 & 47 & 2.35 & .111 & & & \\
\hline \multirow{2}{*}{ Chest measurement - pause } & 14 & 45 & 83.13 & 7.561 & 4.415 & 4.561 & 0 \\
\hline & 16 & 47 & 89.52 & 5.791 & & & \\
\hline \multirow{2}{*}{$\begin{array}{l}\text { Chest measurement - respiratory differ- } \\
\text { ence }\end{array}$} & 14 & 45 & 8.10 & 1.590 & .345 & .836 & .405 \\
\hline & 16 & 47 & 8.39 & 1.769 & & & \\
\hline \multirow{2}{*}{ Sprint $20 \mathrm{~m}$} & 14 & 45 & 3.53 & .254 & .425 & 2.459 & .016 \\
\hline & 16 & 47 & 3.40 & .250 & & & \\
\hline \multirow{2}{*}{ Long jump } & 14 & 45 & 2.03 & .238 & .071 & 5.046 & 0 \\
\hline & 16 & 47 & 2.28 & .243 & & & \\
\hline \multirow{2}{*}{ Vertical jump } & 14 & 45 & 45.19 & 9.049 & 2.177 & 5.576 & 0 \\
\hline & 16 & 47 & 55.36 & 8.450 & & & \\
\hline \multirow{2}{*}{ Maximum Vertical jump } & 14 & 45 & 58.77 & 10.550 & 3.436 & 5.070 & 0 \\
\hline & 16 & 47 & 70.00 & 9.900 & & & \\
\hline \multirow{2}{*}{ Flexibility } & 14 & 45 & 101.38 & 6.290 & .601 & 1.350 & .18 \\
\hline & 16 & 47 & 103.36 & 7.702 & & & \\
\hline \multirow{2}{*}{ "Shuttle" run } & 14 & 45 & 30.79 & 2.997 & .490 & .592 & .555 \\
\hline & 16 & 47 & 30.45 & 2.486 & & & \\
\hline \multirow{2}{*}{ Swift moving along the ground } & 14 & 45 & 16.43 & 1.024 & 3.404 & 2.269 & .026 \\
\hline & 16 & 47 & 15.88 & 1.278 & & & \\
\hline \multirow{2}{*}{ Shooting from position - time } & 14 & 45 & 61.97 & 8.010 & 5.566 & 2.045 & .044 \\
\hline & 16 & 47 & 59.09 & 5.289 & & & \\
\hline \multirow{2}{*}{ Shooting for 2 points } & 14 & 45 & 2.18 & 1.284 & .498 & .111 & .911 \\
\hline & 16 & 47 & 2.15 & 1.197 & & & \\
\hline \multirow{2}{*}{ Shooting for 3 points } & 14 & 45 & 1.36 & .981 & .810 & .928 & .356 \\
\hline & 16 & 47 & 1.55 & 1.059 & & & \\
\hline \multirow{2}{*}{ Free throws } & 14 & 45 & 65.11 & 18.540 & .443 & 3.361 & .001 \\
\hline & 16 & 47 & 51.28 & 20.811 & & & \\
\hline
\end{tabular}


Table 4 analysis shows that the calculated values of t-criterion for some indicators were higher than the critical $\left(\mathrm{t}_{\text {critical }}=1.98\right)$ one. That allowed us, with high guaranteed probability, to reject the zero hypothesis and accept as true the alternative hypothesis according to which the differences observed between the average levels of the signs under study for U14 and U16 were statistically significant. However, the indicators whose empirical values were lower than the critical, showed that the differences were not statistically significant and may be explained by occasional reasons. These are signs bearing information about the obesity degree, chest development degree, suppleness, speed endurance, as well as the ability to score baskets while shooting from position for 2 and 3 points by the young competitors.

Table 5 presents comparative analysis of the average for the U12 and U14 girls. When analyzing the table, we can see that for a greater part of the sings under study, higher values of t-criterion were observed, while for four of the signs, they were lower than the critical $\left(\mathrm{t}_{\text {crit- }}\right.$ ical $=1.98$ ) one, which shows that the existing differences were not statistically significant and may be explained by occasional reasons. These are signs related to horizontal and vertical extension, speed endurance, and the ability to score free throws.

Table 5. Importance of differences for U12 and U14 girls

\begin{tabular}{|c|c|c|c|c|c|c|c|}
\hline Indicators & Age & $\mathbf{N}$ & Mean & $\mathbf{S}$ & $\mathbf{F}$ & $\mathbf{t}$ & Sig. \\
\hline \multirow{2}{*}{ Height } & 12 & 71 & 1.56 & .079 & 4.321 & 7.746 & 0 \\
\hline & 14 & 49 & 1.66 & .062 & & & \\
\hline \multirow{2}{*}{ Weight } & 12 & 71 & 45.14 & 10.306 & .105 & 7.243 & 0 \\
\hline & 14 & 49 & 59.62 & 11.398 & & & \\
\hline \multirow{2}{*}{ BMI } & 12 & 71 & 18.02 & 4.497 & .771 & 4.646 & 0 \\
\hline & 14 & 49 & 21.46 & 3.123 & & & \\
\hline \multirow{2}{*}{ Horizontal extension } & 12 & 71 & 1.55 & .083 & 5.943 & 1.056 & .293 \\
\hline & 14 & 49 & 1.66 & .064 & & & \\
\hline \multirow{2}{*}{ Vertical extension } & 12 & 71 & 2.02 & .103 & 5.951 & 1.242 & .217 \\
\hline & 14 & 49 & 2.14 & .082 & & & \\
\hline \multirow{2}{*}{ Chest measurement - pause } & 12 & 71 & 78.23 & 7.689 & 2.647 & 5.96 & 0 \\
\hline & 14 & 49 & 86.18 & 6.369 & & & \\
\hline \multirow{2}{*}{$\begin{array}{l}\text { Chest measurement - respiratory } \\
\text { difference }\end{array}$} & 12 & 71 & 6.46 & 1.468 & 1.873 & 3.643 & 0 \\
\hline & 14 & 49 & 7.38 & 1.184 & & & \\
\hline \multirow{2}{*}{ Sprint 20m } & 12 & 71 & 4.00 & .332 & .009 & 1.984 & .05 \\
\hline & 14 & 49 & 3.82 & .633 & & & \\
\hline \multirow{2}{*}{ Long jump } & 12 & 71 & 1.65 & .202 & 2.719 & 3.078 & .003 \\
\hline & 14 & 49 & 1.76 & .164 & & & \\
\hline \multirow{2}{*}{ Vertical jump } & 12 & 71 & 29.41 & 6.303 & .409 & 2.717 & .008 \\
\hline & 14 & 49 & 32.41 & 5.377 & & & \\
\hline \multirow{2}{*}{ Maximum Vertical jump } & 12 & 71 & 33.00 & 10.000 & .662 & 3.520 & .001 \\
\hline & 14 & 49 & 38.00 & 6.600 & & & \\
\hline \multirow{2}{*}{ Flexibility } & 12 & 71 & 100.64 & 6.703 & 1.32 & 4.107 & 0 \\
\hline & 14 & 49 & 105.89 & 7.128 & & & \\
\hline \multirow{2}{*}{ "Shuttle" run } & 12 & 71 & 34.43 & 3.113 & .554 & 1.648 & .077 \\
\hline & 14 & 49 & 33.76 & 1.231 & & & \\
\hline \multirow{2}{*}{ Swift moving along the ground } & 12 & 71 & 19.65 & 1.865 & 8.008 & 5.323 & 0 \\
\hline & 14 & 49 & 18.06 & 1.154 & & & \\
\hline
\end{tabular}




\begin{tabular}{lccccccc}
\hline \multirow{2}{*}{ Shooting from position - time } & 12 & 71 & 53.02 & 5.146 & 12.067 & 2.609 & .01 \\
& 14 & 49 & 43.69 & 9.542 & & & \\
\hline \multirow{2}{*}{ Shooting for 2 points } & 12 & 71 & 2.92 & 2.034 & 17.681 & 5.67 & 0 \\
\multirow{2}{*}{ Free throws } & 14 & 49 & 1.10 & 1.123 & & & \\
& 12 & 71 & 4.48 & 1.731 & .780 & 1.301 & .196 \\
\hline
\end{tabular}

Table 6 presents comparative analysis of the average for U14 and U16 girls.

Table 6. Importance of the differences for U14 and U16 girls

\begin{tabular}{|c|c|c|c|c|c|c|c|}
\hline Indicators & Age & $\mathbf{N}$ & Mean & $\mathbf{S}$ & $\mathbf{F}$ & $\mathbf{t}$ & Sig. \\
\hline \multirow{2}{*}{ Height } & 14 & 49 & 1.66 & .062 & 1.763 & 1.441 & .153 \\
\hline & 16 & 53 & 1.68 & .068 & & & \\
\hline \multirow{2}{*}{ Weight } & 14 & 49 & 59.62 & 11.39 & 1.172 & 1.572 & .119 \\
\hline & 16 & 53 & 62.82 & 9.129 & & & \\
\hline \multirow{2}{*}{ BMI } & 14 & 49 & 21.46 & 3.122 & .035 & 1.280 & .204 \\
\hline & 16 & 53 & 22.26 & 3.142 & & & \\
\hline \multirow{2}{*}{ Horizontal extension } & 14 & 49 & 1.66 & .064 & 4.43 & 0.871 & .386 \\
\hline & 16 & 53 & 1.68 & .072 & & & \\
\hline \multirow{2}{*}{ Vertical extension } & 14 & 49 & 2.14 & .082 & 4.434 & 1.036 & .303 \\
\hline & 16 & 53 & 2.16 & .092 & & & \\
\hline \multirow{2}{*}{ Chest measurement - pause } & 14 & 49 & 86.18 & 6.369 & .462 & 1.436 & .154 \\
\hline & 16 & 53 & 87.86 & 5.396 & & & \\
\hline \multirow{2}{*}{$\begin{array}{l}\text { Chest measurement - respiratory } \\
\text { difference }\end{array}$} & 14 & 49 & 7.38 & 1.183 & .011 & 0.583 & .561 \\
\hline & 16 & 53 & 7.52 & 1.259 & & & \\
\hline \multirow{2}{*}{ Sprint $20 \mathrm{~m}$} & 14 & 49 & 3.82 & 0.633 & 1.999 & 0.503 & .616 \\
\hline & 16 & 53 & 3.78 & 0.188 & & & \\
\hline \multirow{2}{*}{ Long jump } & 14 & 49 & 1.76 & 0.164 & 2.369 & 1.175 & .243 \\
\hline & 16 & 53 & 1.80 & 0.221 & & & \\
\hline \multirow{2}{*}{ Vertical jump } & 14 & 49 & 32.41 & 5.377 & 1.102 & 3.851 & 0 \\
\hline & 16 & 53 & 36.78 & 6.033 & & & \\
\hline \multirow{2}{*}{ Maximum Vertical jump } & 14 & 49 & 38.00 & 6.600 & 1.507 & 4.820 & 0 \\
\hline & 16 & 53 & 45.00 & 7.100 & & & \\
\hline \multirow{2}{*}{ Flexibility } & 14 & 49 & 105.89 & 7.127 & 3.114 & 2.619 & .01 \\
\hline & 16 & 53 & 109.23 & 5.713 & & & \\
\hline \multirow{2}{*}{ "Shuttle" run } & 14 & 49 & 33.76 & 1.231 & 1.538 & 3.300 & .013 \\
\hline & 16 & 53 & 32.68 & 1.938 & & & \\
\hline \multirow{2}{*}{ Swift moving along the ground } & 14 & 49 & 18.06 & 1.153 & 1.225 & 4.745 & 0 \\
\hline & 16 & 53 & 17.06 & .960 & & & \\
\hline \multirow{2}{*}{ Shooting from position - time } & 14 & 49 & 43.69 & 29.542 & 15.001 & 2.254 & .026 \\
\hline & 16 & 53 & 55.54 & 23.380 & & & \\
\hline \multirow{2}{*}{ Shooting for 2 points } & 14 & 49 & 1.10 & 1.122 & .249 & 2.915 & .004 \\
\hline & 16 & 53 & 1.8062 & 1.3015 & & & \\
\hline \multirow{2}{*}{ Shooting for 3 points } & 14 & 49 & .7551 & .8787 & 1.931 & 2.406 & .018 \\
\hline & 16 & 53 & 1.2326 & 1.1028 & & & \\
\hline \multirow{2}{*}{ Free throws } & 14 & 49 & 39.1837 & 29.77952 & 6.632 & 2.05 & .038 \\
\hline & 16 & 53 & 50.566 & 24.76156 & & & \\
\hline
\end{tabular}


Differing from the boys, statistically significant differences were not observed along nine signs for the girls because of the values of $t \leq 1.98$. These are signs related to the physical development, speed abilities, and explosive strength of the lower limbs in horizontal plain. Differences were observed only in relation to some signs of the physical preparedness and for all technical skill indicators. That shows that in relation to the selection of $\mathrm{U} 16$ girls, there were some omissions, but on the account of that, the level of the technical preparedness was statistically important in comparison with U14.

\section{DISCUSSION}

Modern basketball development sets up high requirements to coaches and young competitors. Different and varied test batteries exist for control on the sports preparedness of the growing-up basketball players. The Bulgarian Basketball Federation has not set up a requirement for obligatory tests, so their application depends on coaches' wish to control and optimize the school-training process. Well known and established test batteries according to Tsarov (2008), Gyosheva et all (1990), and Tsarova (1990) have been predominantly used in Bulgaria in the last years; however, their results cannot be analyzed and compared with the achievements of the up-to-date competitors; coaches do not have much time, needed for the correct conducting of these tests ( 2 training sessions are required). The last research of a scientific team of $\mathrm{R}$. Tsarova and $\mathrm{M}$. Borukova was done during the period 2012/2015 on young male and female basketball players from 12 to 19 years of age; the authors established that the competitors of today have lower results as compared to the earlier generations. It is a tendency for the results to be reduced by each coming year which imposes the creation of a new test battery and an actual normative system for it. There are various methods for developing norms. Our rich experience in that direction shows that for the sports games (particularly basketball), the use of Sigma method is fully justified (Tsarov, 2012). Normative tables can be developed in various point systems. The 50-rate point system is the most suitable for highly qualified basketball players. It allows recording even the smallest change (in positive or negative direction) of the development level of each of the signs under study (Tsarov, 2013).

\section{CONCLUSION}

The analysis of the data provides us with the reason to consider that the test battery proposed by us fully answers the requirements for control on growing-up basketball players. After an analysis and discussions of the results with the coaches of the participants, it was established that they objectively present the real level status of the male and female young basketball players at the various age groups. Up to now, all coaches of the teams which took part in the sport-pedagogical study with Borukova's (2021) new test battery think that it covers exhaustive information in relation to the physical development, physical preparation, and competitors' technical skills level. They like the fact that the tests are conducted within one training session only, which makes it easier for them; they wish to go on with current and phase tests during the present season. The use of Sigma method allows for the development of normative tables by which the status of each sign (indicator) under study can be easily evaluated. That would help the work of coaches to optimize the school-training process.

\section{ACKNOWLEDGMENT}

The article results from the joint work of the author, second-year higher students with 
major Basketball at "V. Levski" National Sports Academy, 41 licensed coaches from BBF, working with part of the teams under study as well as to all male and female basketball competitors having performed the tests. The author thanks all participants in the study for the correct and collegial relationship.

\section{REFERENCES}

American Alliance for Health, Physical Education, Recreation and Dance (AAHPERD). (1984). Basketball for boys and girls: skill test manual VA: Reston.

Brace, D. K. (1924). Testing basketball techniques. American Physical Education Review 29.

Borukova, M. (2018). Control na sportnata podgotovaka pri 13-14 godishni basketbolistki. Sofia, Bolid ins. // Борукова, М. (2018). Контрол на спортната подготовка при 13-14 годишни баскетболистки. София, Болид-инс

Gigova, V. (2002). Statisticheska obrabotka I analiz na danni, Sofia, NSA-IPB. // Гигова, В. (2002). Статистическа обработка и анализ на данни, София, НСА - ИПБ.

Giocheva, K. Tzarova,R \& Tzarov, K. (1990). Sisrema za kojrol, otzenka I optimtzirane na sportnata podgotovka na momicheta I momcheta - 13-15 godini. Sofia, ETZNPKFKS-IPB, pp.6. // Гьошева, К., Цьров, К. \& Църова, Р. (1990). Система за контрол, оценка и оптимизиране на спортната подготовка на момичета и момчета - 13-15 години. София, ЕЦНПКФКС - ИПБ, стр.6.

Dasheva, D. (1991). Stres I stresovi vazdeistvija v podgotovkata na basketbolisti. Dissertation, VIF. Sofia // Дашева, Д. (1991). Стрес и стресови въздействия в подготовката на баскетболисти, Дис. Труд. ВИФ. София.

Zhelyazkov Ts., Brogli, Ya., Nozharov, P. (1984). Sistema za kontrol i otsenka na efekta ot podgotovkata na sportniya rezerv. Sofi- уа. // Желязков Ц., Брогли, Я., Ножаров, П. (1984). Система за контрол и оченка на ефекта от подготовката на спортния резерв. София.

Zhelyazkov, Ts., Kyolle, V. (1993). Izsledvane na spetsifichnoto funktsionalno natovarvane pri visoko kvalifitsirani basketbolisti. Sport \& Nauka (7). Sofiya. // Желязков, Ц., Кьолле, В. (1993). Изследване на специфичното функционално натоварване при високо квалифицирани баскетболисти. Спорm \& Наука (7). София.

Karalejič, M. \& Jakovljevič, S. (2001). Osnove košarke, Beograd. pp.80-93

Karalejić, M., Jakovljević, M., Macura M. (2011). Anthropometric characteristics and technical skills of 12 and 14 year old basketball players. J. Sport Med. Phys. Fit.; 51, pp.103-110.

Pattison, M. (1990). Basketball: tests and measurements. Australian Basketball Federation. Edgecliff.

Petrov, L. (1998). Basketbol.VTU, V. Tarnovo // Петров, Л. (1998). Баскетбол, ВТУ, В. Търново

Semov, K. (1973). „Edinna programa za sportna podgotovka po basketbol”, Sofiya. // Семов, К. (1973). „Единна програма за спортна подготовка по баскетбол", София.

Temkov, V. (1956). Kontrolni normativi za basketbolista-VFK, 1. Sofiya. // Темков, B. (1956). Контролни нормативи за баскетболиста-ВФК, 1. София.

Tsarov, Kr. (2012). Sastezatelnata efektivnost v basketbola. Sofiya: Bolid ins. // Църов, Кр. (2012). Състезателната ефективност в баскетбола. София: Болид инс.

Tsarova, R., Tsarov, K. (2007). Testova bateriya za nachalen podbor $\mathrm{v}$ basketbola, BFB, Sofiya. // Църова, Р., Цьров, К. (2007). Тестова батерия за начален подбор в баскетбола, БФБ, София.

Tsarova, R., Borukova, M. (2012). Sistema 
za otsenka i kontrol na sportnata podgotvenost na uchenitsite ot sportnite uchilishta, pp. 4971, Bolid ins., Sofiya. // Църова, Р., Борукова, М. (2012). Система за оценка и контрол на спортната подготвеност на учениците от спортните училища, стр. 49-71, Болид инс., София.
Tzarova, R. (2013). Problemi na kontrola v basketbola, Sofia, Bolid ins. // Църова, Р. (2013). Проблемина контрола в баскетбола. София. Болид инс.

Young, G., Moser, H. (1934). A short battery of tests to measure playing ability in women's basketball, Research Quarterly 5.

\section{Corresponding author:}

Mariana Borukova

Department „Basketball, Volleyball, Handball”

National Sports Academy „Vassil Levski”" 21, Acad. Stefan Mladenov Str.

Sofia 1700, Bulgaria E-mail: marianaborukova@gmail.com 